\title{
Proline-Rich Transmembrane Protein 2
}

National Cancer Institute

\section{Source}

National Cancer Institute. Proline-Rich Transmembrane Protein 2. NCI Thesaurus. Code C101622.

Proline-rich transmembrane protein 2 (340 aa, $\sim 35 \mathrm{kDa}$ ) is encoded by the human PRRT 2 gene. This protein may play a role in central nervous system development. 